OPEN ACCESS

Edited by:

Jyoti Prakash Tamang,

Sikkim University, India

Reviewed by: Jashbhai B. Prajapati

Anand Agricultural University, India

S. R. Joshi

North Eastern Hill University, India

${ }^{*}$ Correspondence:

Keshab C. Mondal

mondalkc@gmail.com

${ }^{\dagger}$ These authors have contributed equally to this work

Specialty section:

This article was submitted to

Food Microbiology,

a section of the journal

Frontiers in Microbiology

Received: 12 October 2018

Accepted: 25 March 2019

Published: 24 April 2019

Citation:

Hor PK, Ray M, Pal S, Ghosh K,

Soren JP, Maiti S, Bera D, Singh S,

Dwivedi S, Takó M,

DasMohapatra PK and Mondal KC

(2019) Some Functional Properties

of khambir, an Ethnic Fermented

Cereal-Based Food of Western

Himalayas. Front. Microbiol. 10:730.

doi: 10.3389/fmicb.2019.00730

\section{Some Functional Properties of khambir, an Ethnic Fermented Cereal-Based Food of Western Himalayas}

Papan K. Hor ${ }^{1+}$, Mousumi Ray ${ }^{1+}$, Shilpee Pal't, Kuntal Ghosh ${ }^{2}$, Jyoti P. Soren', Smarajit Maiti3, Debabrata Bera ${ }^{4}$, Somnath Singh ${ }^{5}$, Sanjay Dwivedi ${ }^{6}$, Miklós Takó, Pradeep K. DasMohapatra ${ }^{1}$ and Keshab C. Mondal ${ }^{1 *}$

${ }^{1}$ Bioinformatics Infrastructure Facility Center, Department of Microbiology, Vidyasagar University, Midnapore, India, ${ }^{2}$ Department of Biological Sciences, Midnapore City College, Paschim Medinipur, India, ${ }^{3}$ Department of Biochemistry and Biotechnology, Cell and Molecular Therapeutics Laboratory, Oriental Institute of Science and Technology, Midnapore, India, ${ }^{4}$ Department of Food Technology, Jadavpur University, Kolkata, India, ${ }^{5}$ Division of Nutrition, Defense Institute of Physiology and Allied Sciences, New Delhi, India, ${ }^{6}$ Defence Research Laboratory (Defence Research and Development Organisation), Tezpur, India, ${ }^{7}$ Department of Microbiology, Faculty of Science and Informatics, University of Szeged, Szeged, Hungary

Traditional leavened wheat-based flat bread khambir is a staple food for the highaltitude people of the Western Himalayan region. The health promoting abilities of two types of khambir, yeast added khambir (YAK) and buttermilk added khambir (BAK), were evaluated. A group of microbes like yeast, mold, lactic acid bacteria $(\llcorner A B)$, and Bifidobacterium sp. were abundant in both khambir but in varied proportions. Both are enriched with phenolics and flavonoids. The aqueous extracts of both breads strongly inhibited the growth of enteropathogens. Molecular docking experiments showed that phenolic acid, particularly $p$-coumaric acid, blocked the active sites of $\beta$-glucosidase and acetylcholine esterase (AChE), thereby inhibiting their activities. YAK and BAK showed antiradical and antioxidant activity ranging from 46 to $67 \%$ evaluated using 2,2diphenyl-1-picrylhydrazyl (DPPH), 2,2-azino-bis-3-ethylbenzothiazoline-6-sulfonic acid (ABTS), and ferric reducing/antioxidant power (FRAP) assays. The aqueous extract of both khambir samples protected the arsenic toxicity when examined under an in situ rat intestinal loop model study. The arsenic induced elevated levels of superoxide dismutase (SOD), catalase (CAT), reduced glutathione, lipid peroxidation (LPO) and DNA fragmentation, and transmembrane mitochondrial potential was alleviated by khambir extract. These results scientifically supported its age-old health benefit claims by the consumer at high altitude and there are enough potentialities to explore khambir as a medicinal food for human welfare.

Keywords: fermented khambir, antimicrobial, docking, antioxidant, antitoxicant activity 


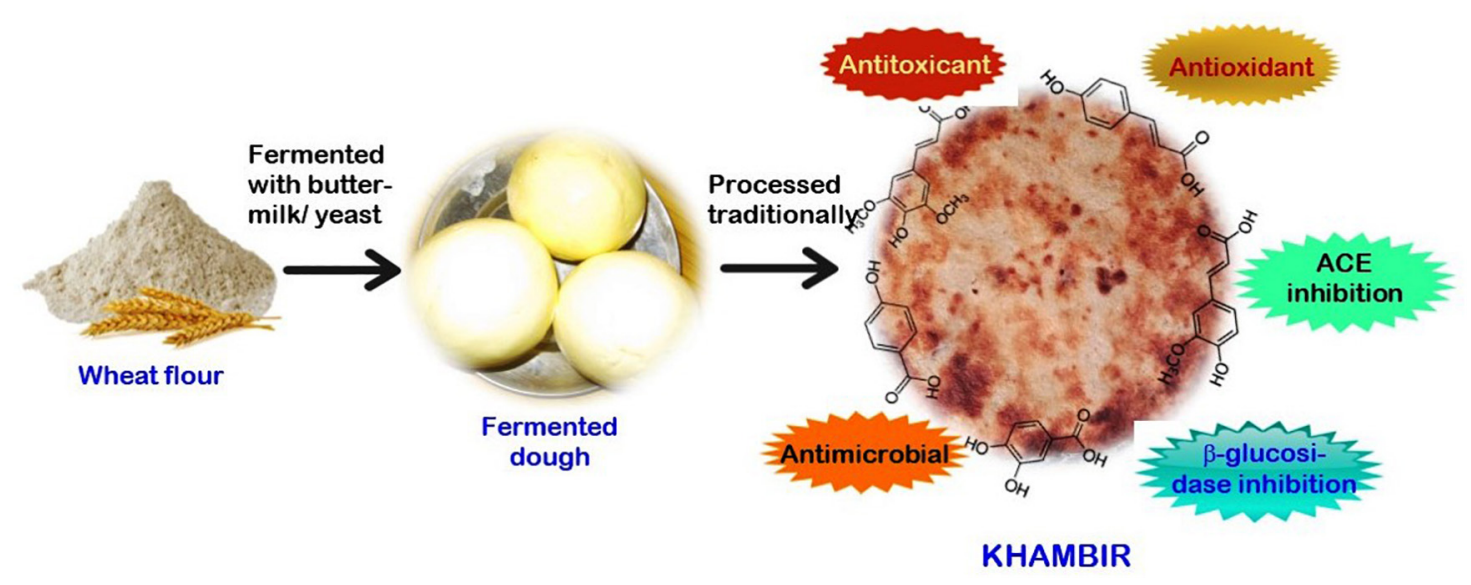

GRAPHICAL ABSTRACT | Health supportive properties of khambir.

\section{INTRODUCTION}

Traditional fermented foods have greater preference in certain communities due to typical characteristics such as flavor, color, and texture (Mondal et al., 2016). Most of the fermented foods contain an increased amount of health beneficial nutraceuticals, bioactive components, and good microbes compared to their unfermented substrate (Tamang et al., 2016). Due to age-old safety and beneficial experiences, scientists have been focused on exploring their nutrient profile, wild microbial resources, and therapeutic components, standardizing process parameters for the welfare of mankind.

Wheat-based handmade flat bread is a traditional and popular staple food, particularly in the Middle East, North Africa, and Central Asia (Parimala and Sudha, 2015). Several types of wheatbased flat bread in Middle Eastern households were documented by Al-Dmoor (2012) and in India by Mir et al. (2014) and Parimala and Sudha (2015). India is the second largest producer of wheat and native people prepare a variety of flat breads with different tastes and textures. Different ingredients like rice/a ricewheat mix (e.g., selroti), finger millet (e.g., ambali), or wheat (e.g., nan, bhaturu or bhatooru, chilra, seera, etc.) are commonly used for the preparation of delicious fermented flat bread in India. There are exceptionally few places where yeast, curd, or butter milk is added to wheat flour, fermented overnight, and then baked using traditional methods. Tagi Khambir or commonly called khambir is a "browned sourdough bread" - a very popular staple food at the high altitudes of the Himalayas like in Leh Ladakh region of Jammu and Kashmir state, India (Angchok et al., 2009) and in a few places in Tibet and China (Tamang, 2010). According to the belief of the native people, this leavened bread can protect them against harsh environmental stresses (extreme cold at around $-25^{\circ} \mathrm{C}$ during winter, strong wind, and low humidity) and provide adequate energy and mouth feeling (Angchok et al., 2009). The culinary practice is also unique and seems to be an inherited food culture of the Indus valley civilization. Rural women have the required knowledge of the proper art of baking this bread. Cleaned wheat flour is mixed with an adequate amount of salt, water, and buttermilk or yeast powder (marketed Baker's yeast). Then the dough is wrapped with a clean cloth and kept in a traditional kitchen overnight. Layers of cloth are wrapped over the container to maintain the temperature. The next day, the fermented dough is divided and hand-shaped into small ball-like structures (each having the weight around $200 \mathrm{~g}$ ). It is then baked initially on hot stones and finally, directly in a fire made of wood or cow dung. It is finished off on the embers inside the fire, using edible oil (Figure 1). It can be stored at room temperature for more than a week. These traditional flat breads are gaining popularity among outsiders due to the rapid growth of "village tourism," "home stay," or "ethnic food tourism" in these regions (Tamang, 2010).

Although the native people believe in the health benefits of khambir, surprisingly no such study has been conducted to validate this. Considering this, we examined the health benefits (antimicrobial, trypsin, acetylcholine, and $\beta$-glucosidase inhibitory activities, antioxidant, and detoxicant activity) of homemade Tagi Khambir. Moreover, the ameliorative role of its extract was tested against arsenic (a globally recognized environmental pollutant and Gr. A carcinogen) induced toxicity, in an in situ loop model study of rat intestine, to prove its detoxification activity.

\section{MATERIALS AND METHODS}

\section{Chemicals}

All the chemicals used in this study are of analytical grade and was procured from standard companies.

\section{Sample Collection and Preparation}

Khambir samples were collected from households in two villages (Sabu and Pheyang which are about $10 \mathrm{~km}$ away from the town of Leh) in the Leh district, Jammu and Kashmir state, India. Three types of preparation, viz., standard white wheat bread (unfermented, used as control), yeast (marketed Baking yeast) added khambir (YAK), and buttermilk added khambir (BAK) 


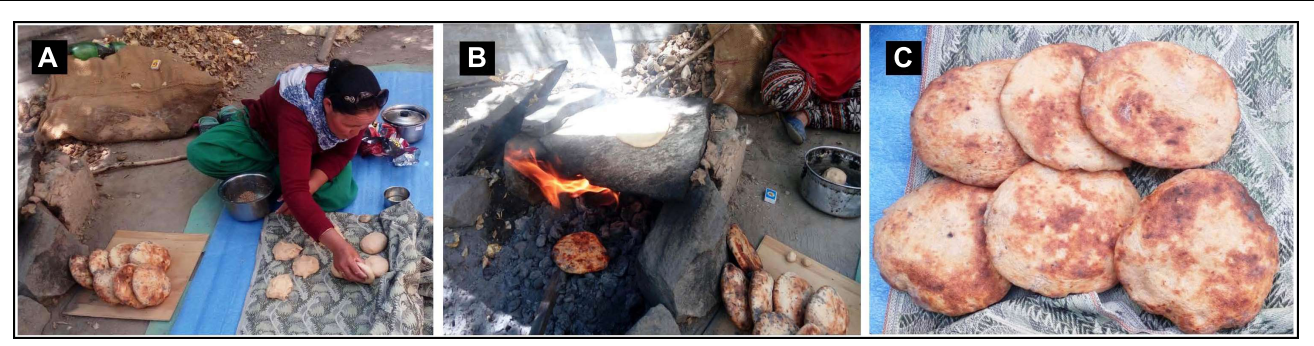

FIGURE 1 | | Traditional process of khambir preparation. After overnight incubation of wheat flour and starter (yeast or buttermilk), the fermented dough is divided, and ball shaped by hand (A). The handmade round-shaped dough is baked over a hot stone and then under direct fire (B). The final cleaned and polished brown bread is ready for consumption (C).

were collected. Then the samples were transferred into a sterile container and transported to the laboratory through an ice box. Bread samples were dried in a food dryer at $55^{\circ} \mathrm{C}$ for $10 \mathrm{~h}$, and then dissolved into sterile distilled water $(0.1 \%, \mathrm{w} / \mathrm{v})$ by homogenization and centrifuged at $2000 \mathrm{~g}$ for $10 \mathrm{~min}$. The supernatant was used as a food extract for further studies.

\section{Microbiological Analysis}

The quantity of the prevalent group of microbes in the food samples (direct sample) was enumerated on the basis of colonyforming units (cfu). The counts of different bacterial group were performed based on their colony morphology and color in various selective and differential agar media. Briefly, $10 \mathrm{~g}$ of the raw sample was mixed with a $100 \mathrm{ml}$ of phosphate buffer saline ( $\mathrm{pH}$ 7.2) and used as stock for the microbial count. The group of lactic acid bacteria (LAB) and Bifidobacterium sp. were cultivated in Rogosa SL agar (supplemented with $0.132 \%$ acetic acid) and Bifidobacterium agar supplemented with Bifidobacterium Selective Supplement (HiMedia, FD285), respectively, and plates were incubated in a $\mathrm{CO}_{2}$ incubator $\left(5 \% \mathrm{CO}_{2}\right.$ ), at $37^{\circ} \mathrm{C}$ (Adak et al., 2013). All of the luxuriant growing colonies were enumerated for the above-mentioned bacteria. Total aerobic bacteria were quantified using Plate Count Agar (PCA) media and incubated at $37^{\circ} \mathrm{C}$ (Adak et al., 2013). Yeast and mold were enumerated by using yeast and mold agar, and Potato Dextrose Agar (PDA) media, respectively, and incubated at $30^{\circ} \mathrm{C}$. The mycelial and round convex colonies were recorded for the mold and yeast counts, respectively. MacConkey agar and Salmonella differential agar were used for the determination of Escherichia coli and Salmonella sp., respectively. The plates were incubated at $35^{\circ} \mathrm{C}$ for 24 to $48 \mathrm{~h}$. The pink red with bile precipitated colonies grown on the MacConkey agar were enumerated for E. coli. Moreover, the colorless and pink red colonies were counted for Salmonella sp. For Vibrio sp. enumeration, the yellow and bluish green color colonies grown on Thiosulfate Citrate Bile salt Sucrose (TCBS) agar base were selected.

\section{Estimation of Total Phenolic Content}

Total phenolic content was determined by the Folin-Ciocalteu method as described elsewhere. One milliliter of bread extract $(100 \mathrm{mg} / \mathrm{ml}), 5 \mathrm{ml}$ of diluted Folin-Ciocalteu phenol reagent (1:10 distilled water), and $4 \mathrm{ml}$ of sodium carbonate solution
$(7 \%, w / v)$ were added sequentially. Soon after mixing the reactants, the test tubes were placed in the dark for $1 \mathrm{~h}$ and the absorbance was recorded at $725 \mathrm{~nm}$ against a reagent blank. The total content of phenolic compounds in extracts was expressed as a gallic acid equivalent (GAE) and $\mathrm{mg} / \mathrm{g}$ of the dry sample.

\section{Extraction of Phenolics and Chromatographic Analysis}

The samples $(300 \mathrm{mg})$ were extracted with $3 \mathrm{ml}$ of methanol/water $(80 / 20, \mathrm{v} / \mathrm{v})$, for $10 \mathrm{~min}$ by sonication at room temperature. After centrifugation at $8000 \mathrm{rpm}$ for $5 \mathrm{~min}$, the supernatant was removed, and the extraction was repeated two times in a similar way. The combined supernatants were evaporated to dryness by centrifugal evaporation. The residues were dissolved in $400 \mu \mathrm{l}$ of methanol/water (80/20, v/v) and filtered through a $0.2 \mu \mathrm{m}$ PTFE membrane filter. A $20 \mu \mathrm{l}$ of the final solution was injected into the HPLC system.

Phenolic compounds were separated on a LUNA-PFP (2) $(3 \mu \mathrm{m}, 150 \mathrm{~mm} \times 4.6 \mathrm{~mm})$ column thermostated at $35^{\circ} \mathrm{C}$. Mobile phase A consisted of methanol/water (10/90, v/v) containing $0.1 \%$ acetic acid, while methanol containing $0.1 \%$ acetic acid served as mobile phase $\mathrm{B}$. The gradient elution was performed as follows: $0.0 \mathrm{~min}, 5 \% \mathrm{~B}$; $6.5 \mathrm{~min}, 25 \% \mathrm{~B} ; 30.5 \mathrm{~min}, 37 \% \mathrm{~B}$; $35.0 \mathrm{~min}, 55 \% \mathrm{~B} ; 37.0 \mathrm{~min}, 95 \% \mathrm{~B} ; 44.0 \mathrm{~min}, 95 \% \mathrm{~B} ; 45.0 \mathrm{~min}$, $5 \% \mathrm{~B}$ and $50.0 \mathrm{~min} ; 5 \% \mathrm{~B}$ for re-equilibration of the column. The flow rate was adjusted to $0.7 \mathrm{ml} / \mathrm{min}$. The injection volume was $20 \mu \mathrm{l}$. Phenolic compounds were monitored at 280 and $320 \mathrm{~nm}$. For quantification, standards (SigmaAldrich, United States) of two subgroups of phenolic acid, viz., hydroxybenzoic acid (protocatechuic acid and p-hydroxybenzoic acid) and hydroxycinnamic acid ( $p$-coumaric acid, ferulic acid, and sinapic acid) were employed.

\section{Estimation of Total Flavonoids Content}

For the estimation of the flavonoid, the bread extract of $0.5 \mathrm{ml}$ was mixed with $0.1 \mathrm{ml}$ of $5 \% \quad \mathrm{C}_{4} \mathrm{H}_{4} \mathrm{O}_{6} \mathrm{KNa} \cdot 4 \mathrm{H}_{2} \mathrm{O}$ [potassium sodium $\mathrm{L}-(+)$ tartrate]. After $5 \mathrm{~min}, 0.1 \mathrm{ml}$ of $10 \%$ aluminum chloride was added to the mixture and made up to $3 \mathrm{ml}$ using distilled water. After incubation at room temperature for $1 \mathrm{~h}$, the absorbance of the reaction mixture was measured at $430 \mathrm{~nm}$ against a blank that 
contained $0.1 \mathrm{ml}$ of distilled water in place of aluminum chloride. The total flavonoid content was expressed $(\mathrm{mg} / \mathrm{g})$ as a quercetin equivalent.

\section{Bioactivities of Khambir Sample Antimicrobial Activity}

Antimicrobial activity of khambir extract was tested (disc diffusion method, $6 \mathrm{~mm}$ ) against different strains of human pathogens (some were locally isolated and characterized, and some were type cultures) like Aeromonas hydrophila SBK1, Salmonella typhi B3274, S. typhi E1590, S. typhi MTCC 734, Shigella dysenteriae 4717, Shigella sonnei RS 1, Staphylococcus aureus MB 13, Streptococcus faecalis MB 15, Micrococcus luteus ATCC 9341, and Vibrio harveyi MTCC 7954. The aqueous extract of the khambir samples $(0.1 \%$, $\mathrm{w} / \mathrm{v}$ ) was filter sterilized and $50 \mu \mathrm{l}$ of the sample was tested against the above-mentioned pathogenic bacteria, which were spread onto the Mueller-Hinton agar (HiMedia, India) media and grown at $37^{\circ} \mathrm{C}$ for $24 \mathrm{~h}$. Tetracycline $(30 \mu \mathrm{g})$ was used as positive control. Thereafter inhibition zones that formed around the disc were measured and compared with an antibiotic.

\section{Effect of Khambir Extract on the Activity of Some Health Indicator Enzymes}

The bread sample was mixed with 10\% diaion HP 20 resin (Sigma) under shaking for $30 \mathrm{~min}$ on a magnetic stirrer. Then the flask contents were eluted with $20 \mathrm{ml}$ methanol. The collected methanol fractions were evaporated in a rotary evaporator (EYELA, Japan) and the residue was dissolved in DMSO and stored at $-20^{\circ} \mathrm{C}$ for further analysis.

\section{$\beta$-Glucosidase Inhibition Assay}

The assay was performed according to the plate assay method as described by Pandey et al. (2013). Briefly, a $10 \mathrm{ml}$ agar solution was prepared by mixing $0.07 \mathrm{~g}$ of agar powder in $0.1 \mathrm{M}$ acetate buffer $(\mathrm{pH} 5.0)$ and dissolved at $80-100^{\circ} \mathrm{C}$; followed by the addition of $1.2 \mathrm{ml}$ of $\mathrm{FeCl}_{3}(0.5 \%$, w/v) solution and $40 \mu \mathrm{l}(0.01 \mathrm{U} / \mathrm{ml})$ of $\beta$-glucosidase (Sigma-Aldrich, sourcealmonds). This mixture was poured onto petri dishes and allowed to settle and firm up. The bread extract of $5 \mu$ l was spotted on the surface of the agar plate. Similarly, conduritol $\beta$-epoxide (Sigma), an irreversible inhibitor (0.75 $\mu \mathrm{g}$ ), was used as a positive control and DMSO without extract was used as a negative control. The plates were incubated at room temperature for $15 \mathrm{~min}$ for an interaction between the enzyme and inhibitor. Later on, $7.0 \mathrm{ml}(0.2 \%$, w/v) of esculin (Himedia, India), the specific substrate for $\beta$-glucosidase, was floated on the surface of an agar plate and again incubated at room temperature for $30 \mathrm{~min}$. Clear zones (CZs) were measured and compared to express the percentage (\%) of enzyme activity or inhibition.

\section{Determination of Trypsin Inhibition}

The trypsin activity was assayed by the casein digestion method (Tripathi et al., 2011). Briefly, $1 \mathrm{ml}$ of enzyme (SRL, India; Bovine pancreas, $1000 \mathrm{U} / \mathrm{mg}, 0.1 \mathrm{mg} / \mathrm{ml}$ ) was incubated alone or with the bread extract for 20 min followed by the addition of $3.0 \mathrm{ml}$ of $1 \%$ casein (in $100 \mathrm{mM}$ Tris- $\mathrm{HCl}$ buffer; $\mathrm{pH} 8.0$ ) at $37^{\circ} \mathrm{C}$ for $20 \mathrm{~min}$. The reaction was stopped by the addition of $3.0 \mathrm{ml}$ of $10 \%(\mathrm{w} / \mathrm{v})$ trichloroacetic acid (TCA). The mixture was then centrifuged at $10,000 \mathrm{~g}$ and absorbance of the supernatant was measured at $280 \mathrm{~nm}$ to estimate the released tyrosine. One unit of trypsin activity was defined as the amount of enzyme that liberates $1.0 \mu \mathrm{g}$ of tyrosine $\mathrm{min}^{-1} \mathrm{ml}^{-1}$ under standard assay conditions.

\section{Acetylcholine Esterase (AChE) Inhibition Assay}

The acetylcholine esterase (AChE) inhibitory activity of the bread extract was evaluated following the method of Elumalai et al. (2015). Briefly, 0.1 M phosphate buffer ( $\mathrm{pH} 8.0,150 \mu \mathrm{l}$ ), food extract solution $(10 \mu \mathrm{l})$, and enzyme solution (earthworm head extract, $20 \mu \mathrm{l}$ ) were mixed and incubated for $15 \mathrm{~min}$ at $25^{\circ} \mathrm{C}$; $10 \mu \mathrm{l}$ of DTNB $(10 \mathrm{mM})$ was then added. The reaction was then initiated by the addition of substrate ( $10 \mu \mathrm{l}$ of acetyl thocholine, $14 \mathrm{mM}$ solution). The formation of the colored product was measured at $410 \mathrm{~nm}$ after $10 \mathrm{~min}$ of incubation. One unit of $\mathrm{AChE}$ activity was defined as the amount of enzyme that liberates $1.0 \mu \mathrm{g}$ of choline $\mathrm{min}^{-1} \mathrm{ml}^{-1}$ under standard assay conditions.

\section{In silico Molecular Docking Experiment}

For the molecular docking study, an X-ray crystallography structure of AChE (PDB ID: 1FSS) with a resolution of $3.0 \AA$ and $\beta$ glucosidase (BG) (PDB ID: IOGS) with a resolution of $2.0 \AA$ were retrieved from the Protein Data Bank (PDB). Active sites or cavities of the selected target proteins were identified using the CAStp server ${ }^{1}$. The target proteins were developed for docking by deleting water and adding polar hydrogen. The structure of the positively correlated phenolic compound ( $p$-coumaric acid) was downloaded from the NCBI PubChem database ${ }^{2}$ and converted into pdb (.pdb) format using Open Babel (O’Boyle et al., 2011). Then docking was performed by using Autodock Tool (version 1.5.6) while PyMol (version 2.0) was used for visualization of the docked structure (Sanner, 1999; Morris et al., 2009).

\section{Assay of in vitro Antioxidant Activity DPPH (2,2-Diphenyl-1-Picrylhydrazyl) Free Radicals Scavenging Test}

The water extraction of khambir $(150 \mu \mathrm{l})$ with a concentration of $100 \mathrm{mg} / \mathrm{ml}$ was mixed with $37.5 \mu \mathrm{l}$ methanolic 2,2diphenyl-1-picrylhydrazyl (DPPH) $\quad(0.75 \quad \mathrm{mM})$ solution. DPPH without khambir extract served as a control. After $20 \mathrm{~min}$ of incubation, absorbance was measured at $517 \mathrm{~nm}$ (Ghosh et al., 2015).

$$
\begin{aligned}
\mathrm{DPPH} \text { scavenging activity }(\%)= & \left(A_{\text {control }}-A_{\text {sample }} / A_{\text {control }}\right) \\
& \times 100
\end{aligned}
$$

where $A_{\text {Sample }}$ is the absorbance of the sample and $A_{\text {control }}$ is the absorbance of the control.

\footnotetext{
${ }^{1}$ http://sts.bioe.uic.edu/castp/

${ }^{2}$ https://pubchem.ncbi.nlm.nih.gov/
} 


\section{ABTS}

\section{(2,2-Azino-Bis-3-Ethylbenzothiazoline-6-Sulfonic Acid) Assay}

2,2-Azino-bis-3-ethylbenzothiazoline-6-sulfonic acid radicalscavenging activity was assayed, following the method of Halder et al. (2014), with necessary modifications. The mixture (1:1 ratio) of ABTS $(7.0 \mathrm{mM})$ and potassium persulfate $(2.45 \mathrm{mM})$ was incubated at $25^{\circ} \mathrm{C}$ overnight before use. The working solution was prepared by diluting the stock solution with methanol to reach an absorbance of $0.7 \pm 0.02$ at $734 \mathrm{~nm}$ ( $\mathrm{A}_{\text {control }}$ ). For measurements, $0.9 \mathrm{ml}$ of the ABTS/ persulfate mixture and $0.1 \mathrm{ml}$ of aqueous extract of khambir were mixed and absorbance was taken immediately after $15 \mathrm{~min}$ at $734 \mathrm{~nm}$. The radical-scavenging activities (\%) in both cases were calculated as follows:

$$
\begin{gathered}
\text { Antioxidant activity }(\%)=\left(A_{\text {control }}-A_{\text {sample }} / A_{\text {control }}\right) \\
\times 100
\end{gathered}
$$

where $A_{\text {Sample }}$ is the absorbance of the sample and $A_{\text {control }}$ is the absorbance of the control.

\section{Measurement of Ferric Reducing/Antioxidant Power (FRAP)}

The reducing power of the khambir extract was measured (Yen and Chen, 1995) by mixing it with an equal volume of phosphate buffer $(0.2 \mathrm{M}, \mathrm{pH}$ 6.6) and then incubating it at $50^{\circ} \mathrm{C}$ for $20 \mathrm{~min}$ with potassium ferricyanide $(1 \%, \mathrm{w} / \mathrm{v})$. The reaction was stopped by addition of TCA $(10 \%, \mathrm{w} / \mathrm{v})$ followed by centrifugation at $3000 \mathrm{rpm}$ for $10 \mathrm{~min}$. The supernatant was mixed with distilled water and ferric chloride $(0.1 \%, \mathrm{w} / \mathrm{v})$ solution, and the absorbance was measured at $700 \mathrm{~nm}$. The reducing power (\%) was calculated using the same equation used for DPPH or ABTS.

\section{In situ Intestinal Loop Model Study to Assess Antitoxic Effect of Khambir}

Inbreed male albino rats $(150 \pm 10 \mathrm{~g})$ were used and fed rat specific standard food for 2 weeks prior to the experiment with Vidyasagar University Animal Ethical clearance (ICE/7-8/68/16 dt. 26.08.2016).

An in situ intestinal loop experiment was conducted as per the method described by Acharyya et al. (2015). Under anesthetize condition (by intramuscular injection of Ketamine-HCl, 22-24 $\mathrm{mg} / \mathrm{kg}$ body wt.), the small intestinal portion was exposed sparingly from the abdominal cavity through a small cut on the cutaneous and abdominal muscle layers. In the small intestine, four loops (each having 2.02.5 inch in length) were created by creating five knots with a sterile cotton thread. These loops were filled $(1 \mathrm{ml})$ sequentially by a syringe with a saline (control), aqueous extract of khambir $(100 \mathrm{mg} / \mathrm{ml})$, sodium arsenite $\left(\mathrm{NaAsO}_{2}\right.$, $250 \mathrm{mM}$ ), and an aqueous mixture of khambir and sodium arsenite, respectively. The intestine was carefully placed back in its original location and the cut site was stitched up. After $24 \mathrm{~h}$, animals were again anesthetized and euthanized by cervical dislocation. The intestinal portion was removed quickly, cleaned, and immediately perfused with ice-cold saline $(0.85 \%$ sodium chloride). Epithelial cells in the inner layer were scraped out from different demarcated locations of the intestine using a Teflon scrapper and homogenized in icecold buffer (phosphate buffer, $0.1 \mathrm{M}, \mathrm{pH}$ 7.4). The homogenate was initially centrifuged at $3000 \mathrm{rpm}$ for $10 \mathrm{~min}$ at $4^{\circ} \mathrm{C}$ in a Remi Cooling Centrifuge (C-24 DL) to separate the nuclear debris. The aliquot obtained was again centrifuged at $10,000 \mathrm{rpm}$ for $20 \mathrm{~min}$ at $4^{\circ} \mathrm{C}$ to obtain the postmitochondrial supernatant, which was used as a source of various enzymes. The protein content of the homogenate was estimated by the Lowry et al. (1951) method, using bovine serum albumin as standard.

\section{Estimation of Superoxide Dismutase (SOD) Activity}

The activity of superoxide dismutase (SOD) was measured following the method of Marklund and Marklund (1974). A reaction mixture was prepared comprising of $2.875 \mathrm{ml}$ Tris- $\mathrm{HCl}$ buffer $(50 \mathrm{mM}, \mathrm{pH} 8.5), 100 \mu \mathrm{l}$ tissue homogenate, and pyrogallol $(24 \mathrm{mM}$ in $10 \mathrm{mM} \mathrm{HCl})$, and the total volume was made $3.0 \mathrm{ml}$. The activity of the enzyme was measured at $420 \mathrm{~nm}$ and the unit (U) was expressed in units/mg protein. One unit of enzyme activity was defined as inhibition of the $50 \%$ auto-oxidation of pyrogallol, and calculated as:

$$
\begin{aligned}
\mathrm{SOD}(\text { units } / \mathrm{mg} \text { protein })= & (\Delta \mathrm{OD} \text { sample } \times \text { OD blank } \times 100) \\
& /(\Delta \text { OD sample } \\
& \times 50 \times \text { Vol. of sample }) .
\end{aligned}
$$

\section{Estimation of Catalase (CAT) Activity}

Catalase (CAT) activity was measured following the method of Aebi (1984). For assay, a reaction mixture was prepared with $2.0 \mathrm{ml}$ phosphate buffer $(0.1 \mathrm{M}, \mathrm{pH} 7.4), 0.05 \mathrm{ml}$ of tissue homogenate, and $0.95 \mathrm{ml}$ hydrogen peroxide $(0.019 \mathrm{M})$ and the total volume was $3.0 \mathrm{ml}$. The activity of the enzyme was measured by taking absorbance at $240 \mathrm{~nm}$. The CAT activity (U) was calculated in terms of nmol $\mathrm{H}_{2} \mathrm{O}_{2}$ consumed/minute/mg protein, with the help of the following formula:

Catalase $($ unit $/ \mathrm{mg}$ of protein $)=(\Delta \mathrm{OD} / \mathrm{min} \times$ Vol. of assay $)$

$$
\begin{aligned}
& \text { / ( } 0.081 \text { of vol. of enzyme } \\
& \text { solution } \times \text { protein content }) \text {. }
\end{aligned}
$$

\section{Estimation of Reduced Glutathione (GSH)}

The method of Jollow et al. (1974) was adopted to measure the GSH level in the tissue. Briefly, $1.0 \mathrm{ml}$ of sulfosalicylic acid (4\%) was mixed with $1.0 \mathrm{ml}$ of tissue homogenate. The sample was incubated for at least $1 \mathrm{~h}$ at $4^{\circ} \mathrm{C}$ and then centrifuged at $1500 \mathrm{rpm}$ for $15 \mathrm{~min}$ at $4^{\circ} \mathrm{C}$ and used as the tissue mixture. The assay mixture contained $2.2 \mathrm{ml}$ phosphate buffer (0.1 M, pH 7.4), $0.4 \mathrm{ml}$ tissue mixture, and $0.4 \mathrm{ml}$ of 5, 5'dithiobis-2-nitrobenzoic acid, (DTNB, $10 \mathrm{mM}$ ) and absorbency was measured at $412 \mathrm{~nm}$. The GSH content was calculated as 
$\mu$ mol DTNB conjugate formed/g tissue using a molar extinction coefficient of $13.6 \times 10^{3} \mathrm{M}^{-1} \mathrm{~cm}^{-1}$ with the help of the following formula:

$$
\begin{aligned}
\mathrm{GSH}= & (\Delta \mathrm{OD} / \mathrm{min} \times \text { Vol. of assay } \times 100) \\
& /(1.36 \text { of mole GSH conjugate/g tissue })
\end{aligned}
$$

\section{Measurement of Lipid Peroxidation (LPO)}

The level of membrane lipid peroxidation (LPO) was assayed following the method of Wright et al. (1981) with some modifications. The reaction mixture comprised of $1.0 \mathrm{ml}$ cell homogenate, $1.0 \mathrm{ml}$ of TCA (10\%), and $1.0 \mathrm{ml}$ TBA $(0.67 \%)$. Then all the tubes were kept in a boiling water bath for $45 \mathrm{~min}$. The tubes were then cooled at room temperature and centrifuged at $5000 \mathrm{rpm}$ for $10 \mathrm{~min}$. The optical density of the supernatant was measured at $532 \mathrm{~nm}$. The level of LPO was measured with respect to malondialdehyde (MDA) formation and results were expressed as the mmol MDA formed/g tissue using a molar extinction coefficient of $1.56 \times 10^{5} \mathrm{M}^{-1} \mathrm{~cm}^{-1}$, with the help of the following formula:

$$
\begin{aligned}
\mathrm{LPO}= & \left(\text { Vol. of assay } \times \mathrm{OD} \times 10^{9}\right) /\left(1.56 \times 10^{5}\right. \\
& \left.\times 10^{3} \text { g tissue }\right) .
\end{aligned}
$$

\section{Analysis of the Mitochondrial Membrane Potential}

The alteration of mitochondrial membrane potential of intestinal epithelial cells of different treatment was measured spectrofluorometrically using Rhodamine 123 (Dash et al., 2014). Cells were seeded in six-well plates at a density of around $2 \times 10^{4} /$ well and incubated with $10 \mu \mathrm{l}$ of $1.5 \mu \mathrm{M}$ Rhodamine 123 at $37^{\circ} \mathrm{C}$ in the dark for $30 \mathrm{~min}$. Then, fluorescence emitting from the Rh123 was measured for $2 \mathrm{~min}$ in a fluorescence spectrophotometer (Hitachi F-7000). The mitochondrial membrane potential was expressed as an emitting fluorescence level at an excitation wavelength of $493 \mathrm{~nm}$ and an emission wavelength of $522 \mathrm{~nm}$.

\section{DNA Fragmentation Study}

The alkaline comet assay was done according to the method of Acharyya et al. (2015). A total of $75 \mathrm{ml}$ of low melting point agarose $(0.5 \%)$ in $\mathrm{PBS}$ at $37^{\circ} \mathrm{C}$ was added to a $25 \mathrm{ml}$ cell suspension $\left(\sim 10^{5}\right.$ cells $\left./ \mathrm{ml}\right)$. The mixture was then dropped onto a glass slide precoated with $1 \%$ agarose. The solidified slides were immersed in ice-cold lysis buffer $(2.5 \mathrm{mM} \mathrm{NaCl}, 85 \mathrm{mM}$ EDTA, $10 \mathrm{mM}$ Trizma base, $1 \%$ Triton X-100, 10\% DMSO, and $1 \%$ sodium lauryl sarcosinate, adjusted to $\mathrm{pH} 10.0$ ) for $1 \mathrm{~h}$. After lysis, the slides were repeatedly washed with PBS and placed in a submarine gel electrophoresis chamber filled with alkaline electrophoresis buffer (0.3 M NaOH and $1 \mathrm{mM}$ EDTA). Then electrophoresis was done at $25 \mathrm{~V}$ and the current was adjusted to $300 \mathrm{~mA}$. Slides were then neutralized with PBS and stained with a solution of $2 \mathrm{mg} / \mathrm{ml}$ ethidium bromide for $2 \mathrm{~min}$. Slides were examined by fluorescence microscope.

\section{Statistical Analysis}

Collected data were presented as the arithmetic mean (mean $\pm \mathrm{SD}$ ). The variations in different analysis results were examined by one-way ANOVA [least significant difference (LSD) testing]. A significant variation was accepted at the level of 5 and $1 \%$ (i.e., $p<0.05$ and $p<0.01$ ) was measured using Sigmastat 11.0 (United States) statistical software. Multiple correlations between the beneficial properties of the control, YAK, and BAK were performed by IBM-SPSS (version 19).

\section{RESULTS AND DISCUSSION}

India is a country which has not lost all of its culture, food habits, and traditions. Most ethnic people still prefer traditional food as a staple diet and these foods are commonly served to celebrate functions, marriages, and rituals. Khambir is a traditional flat bread prepared and consumed in the Ladhak region. The native people believe that it plays a health protective role in this extreme environment. However, this claim has not been scientifically validated thus far. Considering this, we evaluated its functional properties to justify its age-old health benefit claims at high altitudes.

\section{Total Count of Microbes}

The microbial populations of khambir samples were examined and are represented in Table 1 . There were no significant differences in the microbial content of mold, Bifidobacteria, Vibrio sp., E. coli between both types of the khambir samples $(P \leq 0.05)$. However, significant differences of $\mathrm{LAB}$ and yeast counts were observed between the YAK and BAK $(P \leq 0.05)$. The addition of yeast or butter milk as a starter in wheat flour leads to a profound microbial growth during the overnight incubation at room temperature and facilitated sourdough fermentation. Sourdough fermentation with LAB and yeasts leads to leavening and production of acid and $\mathrm{CO}_{2}$ in bread. The created anaerobiosis may have facilitated the growth of Bifidobacterium sp. in the dough. Surprisingly, the amount of mold was significantly higher which might be due to the fermented dough being wrapped with

TABLE 1 | | Enumeration of different group of microbes in both YAK and BAK.

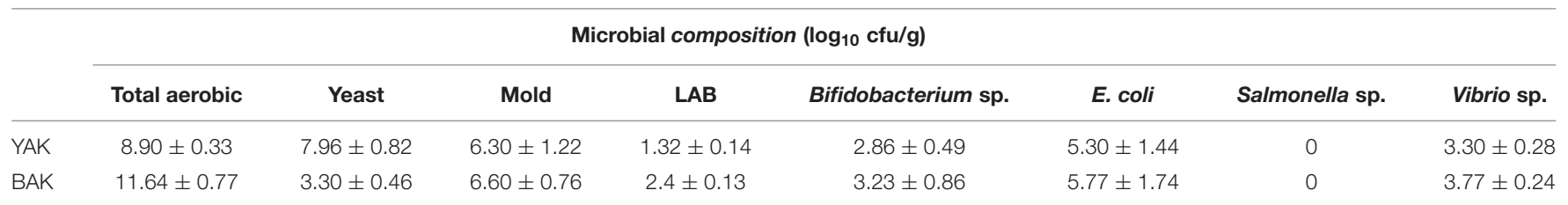


TABLE 2 | | Phenolics and flavonoid content in khambir samples.

\begin{tabular}{|c|c|c|c|c|c|c|c|}
\hline & $\begin{array}{c}\text { Total phenolics } \\
\text { (mg/g) }\end{array}$ & $\begin{array}{l}\text { Protocatechuic } \\
\text { acid }(\mathrm{mg} / \mathrm{kg})\end{array}$ & $\begin{array}{l}\text { p-Hydroxy- } \\
\text { benzoic acid } \\
\text { (mg/kg) }\end{array}$ & $\begin{array}{l}\text { p-Coumaric } \\
\text { acid }(\mathrm{mg} / \mathrm{kg})\end{array}$ & $\begin{array}{l}\text { Ferulic acid } \\
\text { (mg/kg) }\end{array}$ & $\begin{array}{c}\text { Sinapic acid } \\
(\mathrm{mg} / \mathrm{kg})\end{array}$ & $\begin{array}{c}\text { Total } \\
\text { flavonoids } \\
(\mathrm{mg} / \mathrm{g})\end{array}$ \\
\hline YAK & $2.37 \pm 0.21$ & $18.31 \pm 0.46$ & $13.87 \pm 0.57$ & $2.26 \pm 0.23$ & $16.42 \pm 0.82$ & ND & $2.23 \pm 0.4$ \\
\hline BAK & $1.29 \pm 0.2$ & $16.52 \pm 0.43$ & $7.53 \pm 0.60$ & $1.34 \pm 0.33$ & $18.34 \pm 1.68$ & ND & $1.60 \pm 0.2$ \\
\hline
\end{tabular}

Data are presented as means \pm standard deviation of three replicates.

a wet cloth and the storage of the baked product in room temperature for several days. Fermented flat breads in the Indian cuisine have its own unique taste, way of preparation, and use of ingredients, and that leads to different microbial associations. Selroti from the Himalayan region (Yonzan and Tamang, 2010) and ambali from South India (Ramakrishnan, 1980) contain mostly LAB. Whereas, wheat-based bread like Bhatooru from Himachal (Savitri and Bhalla, 2013), seera from the Middle and North of India (Savitri et al., 2012), and nan (Batra, 1986) is dominated by yeasts and very meager populations of LAB. The presence of Vibrio sp. in khambir is of great concern for its hygienic status which may be related to the quality of water (as the native people in the

TABLE 3 | | Antimicrobial activity of aqueous extract of two types of khambir products.

\begin{tabular}{|c|c|c|c|c|}
\hline Target microbes & $\begin{array}{c}\text { YAK (zone of } \\
\text { inhibition, } \\
\text { mm) }\end{array}$ & Al & $\begin{array}{c}\text { BAK (zone of } \\
\text { inhibition, } \\
\text { mm) }\end{array}$ & Al \\
\hline $\begin{array}{l}\text { Aeromonas hydrophila } \\
\text { SBK1 }\end{array}$ & ND & - & ND & - \\
\hline \multicolumn{5}{|l|}{ Salmonella typhi B3274 } \\
\hline & $6.5 \pm 0.6$ & 0.56 & ND & - \\
\hline \multicolumn{5}{|l|}{ Salmonella typhi E1590 } \\
\hline & $6.0 \pm 0.6$ & 0.36 & $3.5 \pm 0.3$ & 0.21 \\
\hline $\begin{array}{l}\text { Salmonella typhi MTCC } \\
734\end{array}$ & $5.5 \pm 0.4$ & 0.47 & $4.5 \pm 0.4$ & 0.39 \\
\hline \multicolumn{5}{|l|}{$\begin{array}{l}\text { Shigella dysenteriae } \\
4717\end{array}$} \\
\hline & $5.2 \pm 1.04$ & 0.46 & $5.5 \pm 0.5$ & 0.49 \\
\hline \multicolumn{5}{|l|}{ Shigella sonnei RS 1} \\
\hline & ND & - & ND & - \\
\hline \multicolumn{5}{|l|}{$\begin{array}{l}\text { Staphylococcus aureus } \\
\text { MB } 13\end{array}$} \\
\hline & $7.5 \pm 0.8$ & 0.63 & ND & - \\
\hline \multicolumn{5}{|l|}{$\begin{array}{l}\text { Streptococcus faecalis } \\
\text { MB } 15\end{array}$} \\
\hline & $6.2 \pm 0.6$ & 0.65 & ND & - \\
\hline \multicolumn{5}{|l|}{$\begin{array}{l}\text { Micrococcus luteus } \\
\text { ATCC } 9341\end{array}$} \\
\hline & $7.0 \pm 0.6$ & 0.56 & $7.2 \pm 0.7$ & 0.58 \\
\hline \multicolumn{5}{|l|}{$\begin{array}{l}\text { Vibrio harveyi MTCC } \\
7954\end{array}$} \\
\hline & $8.5 \pm 0.8$ & 0.94 & $6.5 \pm 0.7$ & 0.76 \\
\hline
\end{tabular}

Himalayan region use glacier water directly for household purpose). However, the pathogenic property of an organism depends on the strain and host specificity as reflected by the regular consumption of such breads by the native people of the Himalayan region. Tamang et al. (2015) mentioned that about $80 \%$ of traditional fermented foods that are prepared through natural fermentation may contain functional, nonfunctional, and pathogenic microorganisms. The prevalence of pathogenic bacteria such as S. aureus, Bacillus cereus, E. coli, Campylobacter, Vibrio cholerae, Aeromonas, Klebsiella, Shigella sp., and Salmonella among others in traditional fermented foods was also documented by Abriouel et al. (2017). Additionally, microbial interplay (enzymes and metabolites) during the course of sourdough fermentation can delay starch digestibility leading to lower glycemic responses, reduced gluten content, and other antinutrients, modulates accessibility of bioactive components, and improves mineral bioavailability, thus enhancing gut health (Poutanen et al., 2009).

\section{Phenolic and Flavonoid Content of Khambir}

It was estimated that the phenolic content of YAK and BAK was 2.37 and $1.29 \mathrm{mg} / \mathrm{g}$, respectively (Table 2), which is a much higher value than the unfermented or unprocessed wheat flour of Indian varieties (Punia and Sandhu, 2016) as well as Chinese varieties (Li et al., 2015). Additionally, a significant or comparatively higher amount of phenolic acids like protocatechuic acid, $p$-hydroxybenzoic acid, $p$-coumaric acid, and ferulic acid were also present in the YAK and BAK (Table 2). Similarly, flavonoid content in the fermented leavened bread was also increased many fold (1.63$2.23 \mathrm{mg} / \mathrm{g}$ in the khambir and $80-100 \mathrm{mg} / \mathrm{g}$ in unfermented wheat flour as reported by Punia and Sandhu, 2016]. During fermentation, microbes originating from hydrolytic enzymes (cellulases, esterases, glycosidase, polyphenol hydrolase, etc.) may lead to the branching and defabrication of the cellulosic backbone as well as polyphenolic structures; therefore, phenolics and flavonoid compounds are detached from the anchoring molecule and become free. Dietary flavonoids and phenolic acids have attracted much interest recently because they have a variety of beneficial biological properties and play an important role in the protection and prevention of many human diseases (Jalal et al., 2015).

\section{Antimicrobial Activity of Water Extract of Khambir}

The antimicrobial activity of the aqueous extracts of khambir samples was tested against different strains of enteropathogens 

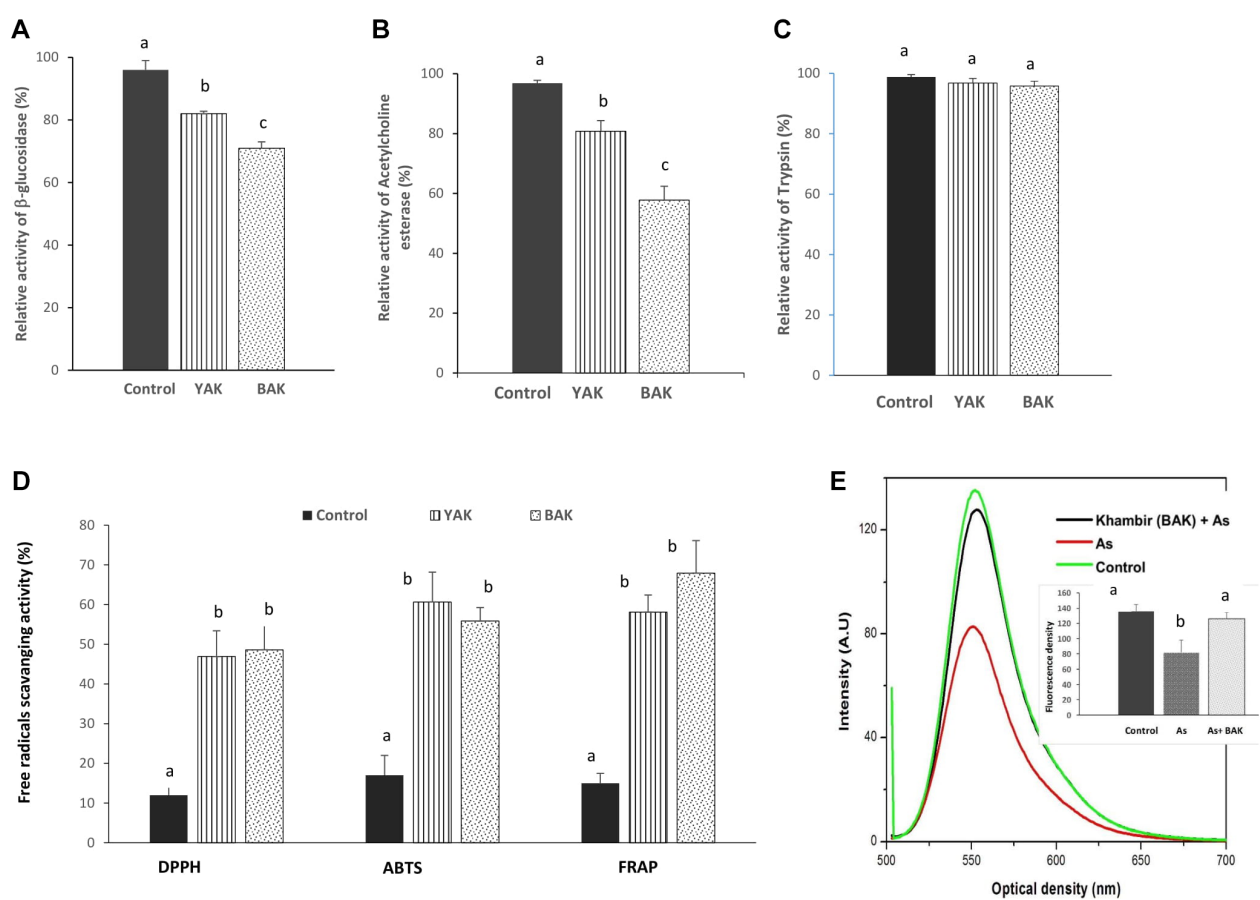

FIGURE 2 | | Evaluation of bioactivities of aqueous extract of yeast added khambir (YAK) and buttermilk added khambir (BAK). Changes of $\beta$-glucosidase (A), acetylcholine esterase (B), trypsin (C) inhibitory activities, and in vitro antioxidant (D) activities (DPPH, ABTS, FRAP) of fermented khambir, i.e., YAK and BAK in respect to control (unfermented) were determined. The activity of enzymes (without any additive) was considered as 100\%. (E) The alteration of mitochondrial transmembrane potential in respect to emitted fluorescence level of Rhodamine 123 during exposure of arsenic and arsenic + khambir extract (BAK) in in situ intestinal loop model study. The control is indicated the fluorescence intensity of control tissue. Data presented as the mean \pm standard deviation of five replicates. Different superscripts (alphabet) on the bar indicated the level of significance difference $(p<0.05)$ among respective groups.

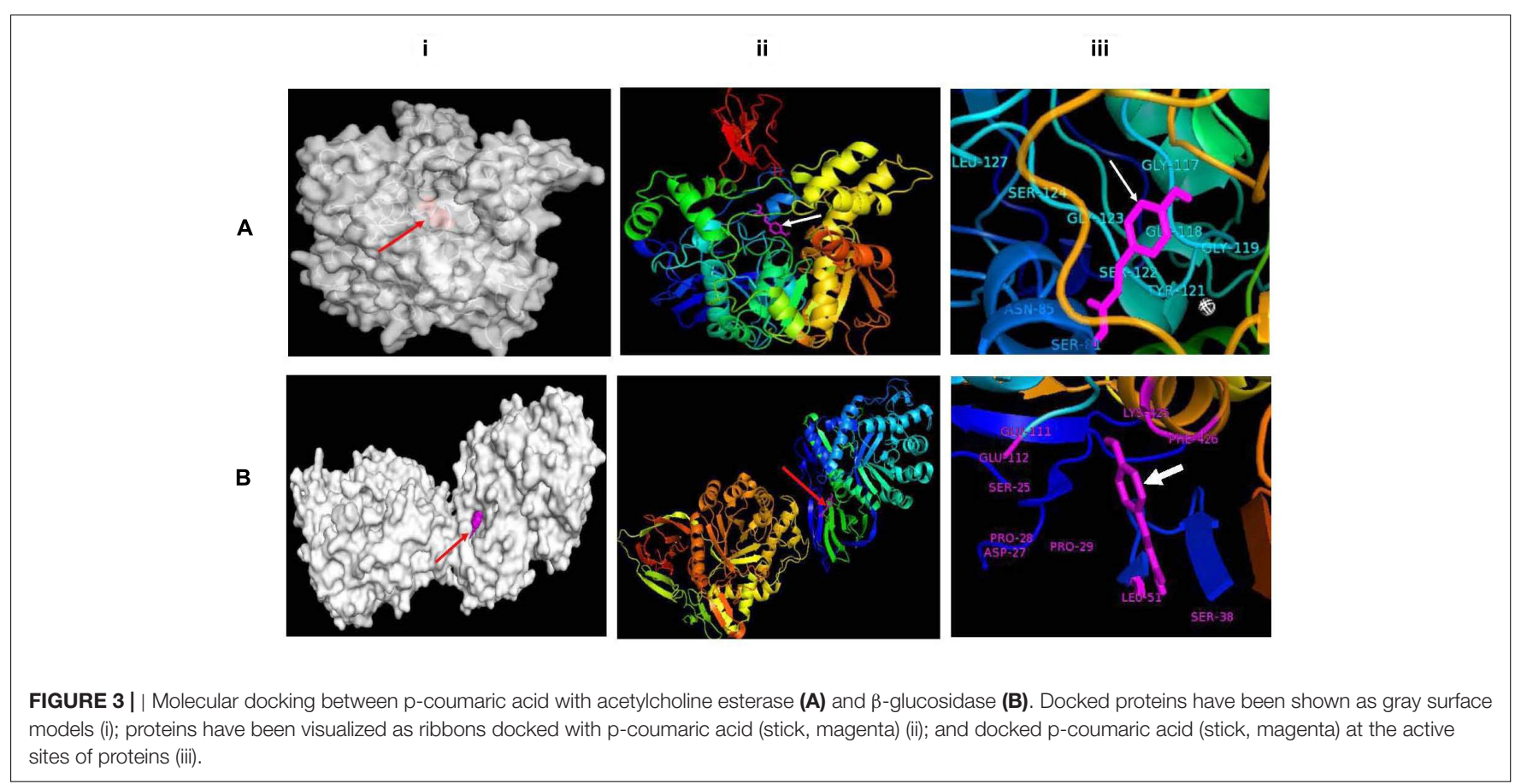

and other organisms (Table 3). It was found that YAK exerted more strain specific antibiosis, particularly against enteropathogens like S. typhi, S. dysenteriae, S. faecalis, and
$V$. harveyi than BAK. The YAK also showed significant inhibitory effects against $S$. aureus, whereas the killing effect of BAK was more prominent against $M$. luteus. The results 
TABLE 4 | | Activity of antioxidant defense related biomarkers in intestinal epithelia during exposure of arsenic.

\begin{tabular}{|c|c|c|c|c|}
\hline Group & SOD (U) & Catalase (U) & MDA (nM/g) & GSH (mg/g) \\
\hline Untreated control & $1.72 \pm 0.03$ & $1.87 \pm 0.07$ & $119.42 \pm 6.65$ & $31.43 \pm 1.27$ \\
\hline Khambir & $1.75 \pm 0.12$ & $1.92 \pm 0.06$ & $92.46 \pm 4.34^{*}$ & $31.87 \pm 2.83$ \\
\hline Arsenic & $0.64 \pm 0.04 * *$ & $1.19 \pm 0.06^{* *}$ & $165.24 \pm 6.2^{* *}$ & $49.82 \pm 5.86^{* *}$ \\
\hline YAK + arsenic & $1.17 \pm 0.04^{*}$ & $1.55 \pm 0.05$ & $104.42 \pm 5.72$ & $38.43 \pm 5.66^{*}$ \\
\hline BAK + arsenic & $1.62 \pm 0.03$ & $1.85 \pm 0.05$ & $96.04 \pm 3.45^{*}$ & $35.19 \pm 4.11$ \\
\hline
\end{tabular}

Data are presented as means \pm standard deviation $(n=5)$. ${ }^{*} p<0.05$ and ${ }^{* *} p<0.01$ are the level of significance difference compared with the control group.
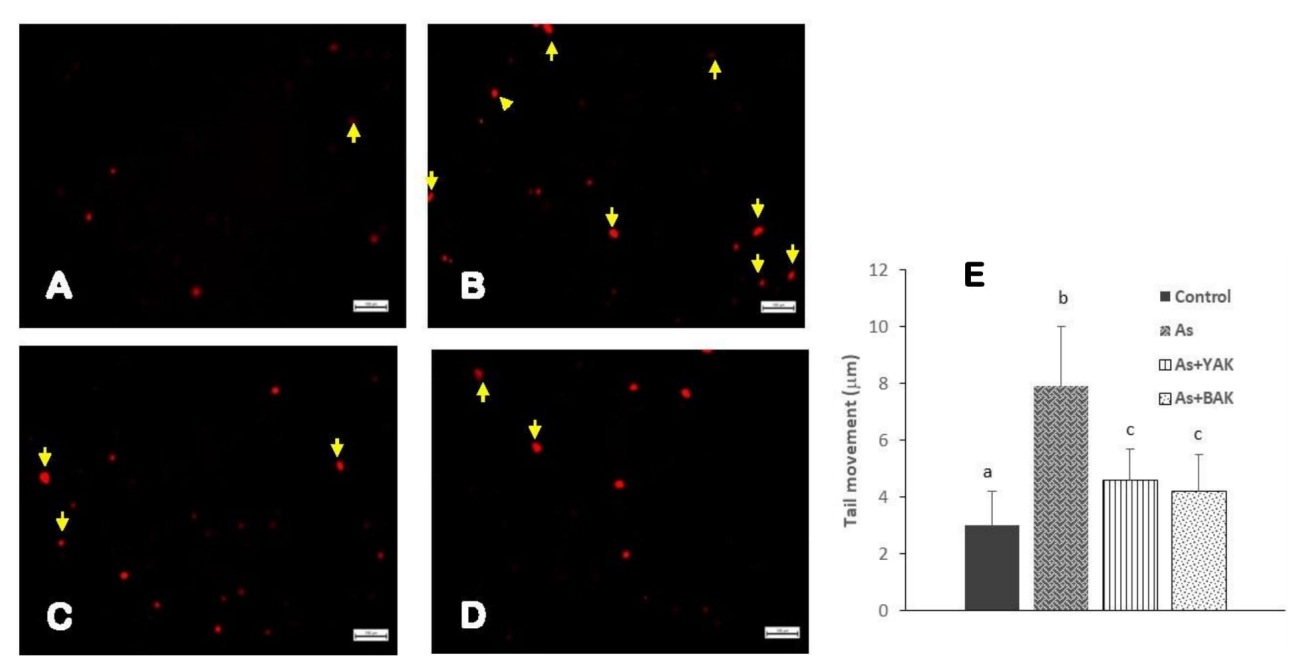

FIGURE 4 | | Determination of the genotoxic protective effects of khambir extracts against arsenic toxicity by Comet assay. Fluorescent microscopic image of (A) control tissue, (B) arsenic treated, (C) co-supplementation of arsenic and YAK, and (D) co-supplementation of arsenic and BAK; (E) graphical representation of the comet tail length of different experiments. The comet tail length was calculated as the distance between the end of nuclei heads and end of each tail. Values are expressed as the mean $\pm \mathrm{SD}(n=100)$; different superscripts (alphabet) on the bar indicate the different levels of significance $(p<0.05)$ among respective groups.

indicated that the reactive metabolites that evolved during fermentation act as a natural preservative in this food. The strain specific and variable antimicrobial effect of natural medicines is a common phenomenon and many factors like $\mathrm{pH}$, extracting solvent and techniques, dilution, culturing media, and source of microorganism are very important and can alter the interaction of the active ingredients with medicinal flora (Rios and Recio, 2005). The antibiosis of the tested food samples was very significant and comparable with commercial antibiotics like tetracycline, which is commonly used as a food preservative (Table 3).

\section{$\beta$-Glucosidase (BG), Acetylcholine Esterase (AChE), and Trypsin Inhibitory Potentialities of Khambir Extracts}

Glucosidase inhibitors have significant therapeutic potential in the treatment of metabolic diseases and disorders like diabetes, obesity, human immune deficiency virus infection, metastatic cancer, lysosomal storage disease, etc. (Pandey et al., 2013). Over 100 glycosidase inhibitors have been isolated from plants and microorganisms (Pandey et al., 2013). A group of microbes originating from $\beta$-glucosidase inhibitors like acarbose, voglibose, valienamine, adiposin-1, and trestatin-B are commercially exploited as anti-diabetic drugs which can reduce sugar digestion (undigested resistant starch) and assimilation into the body (Kulkarni-Almeida et al., 2011). Both khambir preparations, YAK and BAK exhibited 18 and 29\% inhibition of $\beta$-glucosidase activity (Figure $\mathbf{2 A}$ ), establishing them as a useful diabetic diet. Our experimental results provide clues for the blood sugar lowering abilities of sourdough bread as it has previously been reported that sourdough bread consumption can lower post-prandial blood glucose and improve insulin and GLP-1 responses in human subjects (Maioli et al., 2008). In addition, the aqueous extract of YAK and BAK also exerted anti-AChE activity by inhibiting 19.2 and $42.2 \%$ of the original activity (Figure 2B). The occurrence of AChE inhibitors in natural resources has been well documented and characterized, but the quest for new inhibitors remains crucially important owing to their therapeutic potential in the treatment of neurological disorders such as Alzheimer's disease, senile dementia, ataxia, myasthenia Gravis, and Parkinson's disease (Elumalai et al., 2015). The potentialities of BAK have been proven to be more profound, with respect to the inhibition of $\beta$-glucosidase and AChE activity, than YAK, and this may relate to the abundance of a consortium of reactive metabolites particularly phenolic constituents in the khambir product. 


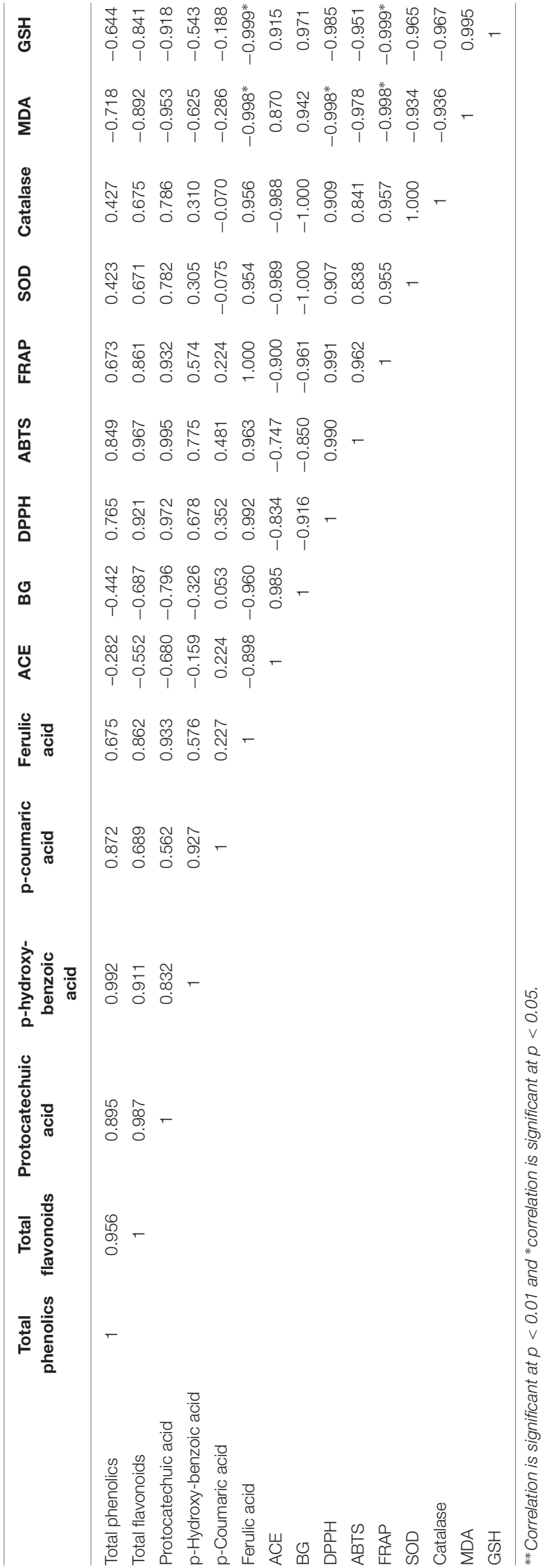

Together with the experimental results and statistical relationship, molecular docking experiments were performed for a better understanding of how the phenolic compound especially $p$-coumaric acid interacts with both the AChE and BG enzyme. In the presence of certain functional groups, such as hydroxyl, carboxyl, and acrylic acid groups, p-coumaric acid can act as a hydrogen bond acceptor or donor, which seems to increase the potency of inhibiting the activity of AChE and BG. Molecular docking analysis showed that $p$-coumaric acid has an optimum binding affinity ( $\Delta \mathrm{G}$ of $-6.8 \mathrm{kcal} / \mathrm{mol}$ ) with a molecular target in the second cavity of the predicted active sites of $\mathrm{AChE}$ and the amino acids in this site of the enzyme like SER-81, ASN-85, GLY-117, GLY 118, GLY-119, TYR-121，SER-122，GLY-123，SER-124, and LEU-127 formed H-bonds with the phenolic compound (Figure 3A). On the other hand, $p$-coumaric acid has blocked the activity of BG by possibly binding at the third cavity of the predicted active sites with an optimum binding energy or binding affinity of $-7.6 \mathrm{kcal} / \mathrm{mol}$. This interaction occurs via amino acids like ASP-27, PRO-28, PRO-29, SER-38, LEU51, GLU-111, GLU-112, LYS-425, and PHE-426 at the active site (Figure 3B). The calculated absolute binding free energies in between -6.8 to $-7.6 \mathrm{kcal} / \mathrm{mol}$ indicated that a number of relatively weak chemical interactions (non-covalent bonds) stabilize the conformations and the interactions between the molecules. This result clearly documents that a functional component of khambir is phenolics, which can specifically bind and inhibit the activities of both BG and AChE. A similar pattern of interaction for the inhibition of angiotensinconverting enzyme with the phenolic acids was also observed by Shukor et al. (2013).

Both extracts of khambir were non-responsive to trypsin activity (Figure 2C). A reduction in trypsin inhibitory activity during natural lactic acid fermentation of cereals was reported by Osman (2011). This indicates that the khambir has no such adverse effect on protein digestion.

\section{Assay of in vitro Antioxidant Activity}

Recently, there has been increased interest on antioxidant nutrients, which have the ability to scavenge free radicals in the system and neutralize them before they do any damage to body cells. A number of methods are also available to determine in vitro antioxidant activity each with their own specific reaction principles; therefore, researchers employ many methods simultaneously to obtain a clear picture of the antioxidant activity. In this study, DPPH, ABTS, and ferric reducing/antioxidant power (FRAP) methods were employed to evaluate the antioxidant potentialities of the aqueous extract of khambir.

The activity of DPPH, ABTS, and FRAP of control (unfermented), YAK, and BAK are shown in Figure 2D. The DPPH, ABTS, and FRAP activity of the control sample was 12, 17 , and $15 \%$; for YAK was $46.90,60.67$, and $58.11 \%$; and for BAK was $48.62,55.85$, and $67.92 \%$, respectively (Figure $2 D$ ). This result indicated that antioxidative potentialities of wheat flour were significantly $(p<0.05)$ improved due to fermentation by a consortium of microbes. 
The "antioxidant power" of the khambir is greatly related to its high phenolic content, as these molecules have the innate ability to donate a hydrogen or electron. They have the ability to delocalize the unpaired electron of free radicals within the aromatic structure (Jalal et al., 2015; Li et al., 2015; Punia and Sandhu, 2016), thereby exhibiting various physiological activities including anti-inflammatory, antiallergic, anticarcinogenic, antihypertensive, anti-arthritic, and antimicrobial activities.

\section{Antioxidant and Antitoxic Action of Khambir: In situ Experiment in Rat Intestine}

The activities of SOD and CAT in the control and experimental groups are shown in Table 4. Arsenic-induced depletion $(p<0.01)$ of SOD and CAT activity was found in the respective group compared to the controls. Co-supplementation of the khambir, along with arsenic, significantly $(p<0.05)$ elevated the levels of SOD and CAT compared to the arsenic aloneexposed groups.

The administration of khambir alone diminished the level of MDA formation compared to normal levels in intestinal tissues. Arsenic treatment resulted in a significant $(p<0.01)$ elevation of the MDA level compared to the control group. Administration of khambir (YAK and BAK), along with arsenic, antagonized the toxic effects of arsenic that were reflected by the significant $(p<0.05)$ decrease of MDA levels compared to the arsenic alone-exposed groups (Table 4).

The content of GSH increased about 36\% $(p<0.05)$ in the intestinal epithelia when exposed to arsenic compared to the control. Simultaneous khambir (both YAK and BAK) treatment with arsenic significantly ( $p<0.05)$ decreased the GSH level in the tissue compared to the arsenic alone-treated groups (Table 4).

Arsenic toxicity leads to the disruption of the mitochondrial membrane architecture, which is reflected by the significant reduction $(p<0.05)$ of the mitochondrial transmembrane potential compared to the control (Figure 2E). Mitochondrial membrane permeability disruption is associated with a lack of rhodamine 123 retention and a decrease in fluorescence. Khambir extract protects the mitochondrial membrane from arsenic toxicity which was noted by the level of fluorescence intensity near the control level (Figure 2E).

The comet assay was carried out to measure the singlestrands DNA breaks in the intestinal epithelial cells of the control, arsenic treatment, and arsenic along with khambir treatment (Figure 4). Results showed an enhanced number of tail migration (DNA strand break) in the arsenic-treated group, which was significantly restrained in the khambir supplemented arsenic-exposed group. The extrusion of the damaged DNA from the majority of cells in the arsenic treated group was clearly visualized (morphometric analysis) by noting the comet tail length (Figure 3). Supplementation of khambir extracts antagonized the toxic effects of arsenic, resulting in a lower amount of DNA damage as well as comet tail length as compared to arsenic alone.

Khambir, particularly BAK extract, exhibited strong protection against arsenic induced modification of the enzymatic antioxidant defense system, by restoring the activities of SOD and CAT, preventing LPO, restoring the GSH pool and mitochondrial transmembrane potential, and above all preventing DNA fragmentation from the harsh toxic effects of arsenic. Khambir extract, particularly its phenolic constituents, may alleviate arsenic toxicity by means of its antioxidant components via a number of mechanisms, including the protection of target molecules (lipids, proteins, and nucleic acids) from oxidative damage (by neutralizing the generated free radicals), suppressing the inflammatory response, modulating vascular homeostasis, and improving the cellular defense system by altering the expression at the gene level (Jalal et al., 2015; Li et al., 2015). The dietary fiber (1.2 $\mathrm{g} \%$ ) of khambir may also play a pivotal role in detoxification by entrapping arsenic before exerting any toxicity (Abdel-Salam et al., 2010).

\section{Multiple Correlation}

Table 5 shows the correlation coefficient $(r)$ between total phenolic, flavonoid, phenolic acids, inhibition of AChE and $\beta$-glucosidase, in vitro antioxidant activities, and in vivo antioxidant parameters altered in arsenic treated rats during supplementation of BAK. The phenolics and flavonoids have a strong relationship with the parameters like in vitro and in vivo antioxidant properties, and inhibition of AChE and $\beta$-glucosidase activities as an $r$-value lies in between +1 to -1 . A strong positive correlation was observed between total phenolics, total flavonoids, protocatechuic acid, p-hydroxybenzoic acid, ferulic acid, $p$-coumaric acid, DPPH, ABTS, FRAP, SOD, and CAT. Among the phenolics, $p$-coumaric acid exhibited a strong position correlation with the inhibition of AChE and $\beta$-glucosidase. In contrast, a negative correlation was obtained between the phenolics and the content of GSH and MDA.

\section{CONCLUSION}

This study clearly demonstrated that both types of khambir, YAK and BAK, carry health benefits and are rich in phenolics, as they exhibit significant antimicrobial, antioxidant, antiradical, and anti-toxic effects. Additionally, a group of food graded microbes in the product can provide some added advantages to consumers. Thus, the experimental evidence supports its age-old claim as a healthy and protective food source against environmental stresses. Further, scientific intervention is urgently needed to improve its hygienic status which will expand its market demand as well as pave the way for economic and livelihood development of the ethnic people of the Leh-Ladakh regions.

\section{ETHICS STATEMENT}

This study was carried out in accordance with the recommendations of Vidyasagar University Animal Ethical clearance (ICE/7-8/6-8/16 dt. 26.08.2016) with written informed consent from all subjects. The study and protocol were reviewed and approved by the Institutional Ethics Committee (IEC) of Vidyasagar University. 


\section{AUTHOR CONTRIBUTIONS}

The trial was conceived by $\mathrm{PH}, \mathrm{MR}, \mathrm{SM}, \mathrm{PD}$, and KM. KM designed the study. PH, MR, and SM conducted the research. SP, MT, KG, and PH analyzed the data. DB, SS, SD, and KM prepared the manuscript. KM had the primary responsibility of the final content. All authors read and approved the final manuscript.

\section{FUNDING}

The authors are thankful to the SEED Division, Department of Science and Technology (DST), New Delhi, India [Ref. No.

\section{REFERENCES}

Abdel-Salam, A. M., Al-Dekheil, A., Babkr, A., Farahna, M., and Mousa, H. M. (2010). High fiber probiotic fermented mare's milk reduces the toxic effects of mercury in rats. N. Am. J. Med. Sci. 2, 569-575. doi: 10.4297/najms.2010.2569

Abriouel, H., Knapp, C. W., Gálvez, A., and Benomar, N. (2017). "Antibiotic resistance profile of microbes from traditional fermented foods," in Fermented Foods in Health and Disease Prevention, eds J. Frias, C. Martinez-Villaluenga, and E. Peña (Cambridge: Academic Press), 675-704. doi: 10.1016/B978-0-12802309-9.00029-7

Acharyya, N., Ali, S. S., Deb, B., Chattopadhyay, S., and Maiti, S. (2015). Green tea (Camellia sinensis) alleviates arsenic-induced damages to DNA and intestinal tissues in rat and In Situ intestinal loop by reinforcing antioxidant system. Environ. Toxicol. 30, 1033-1044. doi: 10.1002/tox.21977

Adak, A., Maity, C., Ghosh, K., Pati, B. R., and Mondal, K. C. (2013). Dynamics of predominant microbiota in the human gastrointestinal tract and change in luminal enzymes and immunoglobulin profile during high-altitude adaptation. Folia Microbiol. 58, 523-528. doi: 10.1007/s12223-013-0241-y

Aebi, H. E. (1984). Catalase in vitro. Methods Enzymol. 105, 121-126. doi: 10.1016/ S0076-6879(84)05016-3

Al-Dmoor, H. M. (2012). Flat bread: ingredients and fortification. Qual. Assur. Saf. Crop. 4, 2-8. doi: 10.1111/j.1757-837X.2011.00121.x

Angchok, D., Dwivedi, S. K., and Ahmed, Z. (2009). Traditional foods and beverages of Ladakh. Indian J. Tradit. Knowl. 8, 551-558. doi: 10.1186/17464269-10-75

Batra, L. R. (1986). "Microbiology of some fermented cereals and grains legumes of India and vicinity," in Indigenous Fermented Food of Non-Western Origin, eds C. W. Hesseltine and H. L. Wang (Berlin: the University of California), 85-104.

Dash, S. K., Ghosh, T., Roy, S., Chattopadhyay, S., and Das, D. (2014). Zinc sulfide nanoparticles selectively induce cytotoxic and genotoxic effects on leukemic cells: involvement of reactive oxygen species and tumor necrosis factor alpha. J. Appl. Toxicol. 34, 1130-1144. doi: 10.1002/jat.2976

Elumalai, K., Ali, M. A., Elumalai, M., Eluri, K., and Srinivasan, S. (2015) Acetylcholinesterase enzyme inhibitor activity of some novel Pyrazinamide condensed 1,2,3,4-tetrahydropyrimidines. Biotechnol. Rep. 5, 1-6. doi: 10.1016/ j.btre.2014.10.007

Ghosh, K., Ray, M., Adak, A., Halder, S. K., Das, A., Jana, A., et al. (2015). Role of probiotic Lactobacillus fermentum KKL1 in the preparation of a rice based fermented beverage. Biores. Technol. 188, 161-168. doi: 10.1016/j.biortech.2015. 01.130

Halder, S. K., Jana, A., Das, A., Paul, T., DasMohapatra, P. K., Pati, B. R., et al. (2014). Appraisal of antioxidant, anti-hemolytic and DNA shielding potentialities of chitosaccharides produced innovatively from shrimp shell by sequential treatment with immobilized enzymes. Food Chem. 158, 325-334. doi: 10.1016/j.foodchem.2014.02.115

Jalal, T. K., Ahmed, I. A., Mikail, M., Momand, L., Draman, S., Isa, M. L., et al. (2015). Evaluation of antioxidant, total phenol and flavonoid content and antimicrobial activities of Artocarpus altilis (Breadfruit) of underutilized tropical fruit extracts. Appl. Biochem. Biotechnol. 175, 3231-3243. doi: 10.1007/ s12010-015-1499-0
SEED/TSP/CODER/005/2012 (G), dt. 14/07/2015] for financial support for this work.

\section{ACKNOWLEDGMENTS}

The authors are thankful to the villagers of Pheyang, Leh, Jammu and Kashmir State for sample preparation and other support. The authors are also thankful to Madhurima Neogi (Assistant Professor, Tamralipta Mahavidyalaya) for help in improving the English of the manuscript.

Jollow, D. J., Mitchell, J. R., Zampaglione, N. A., and Gillette, J. R. (1974). Bromobenzene-induced liver necrosis. Protective role of glutathione and evidence for 3, 4-bromobenzene oxide as the hepatotoxic metabolite. Pharmacology 11, 151-169. doi: 10.1159/000136485

Kulkarni-Almeida, A. A., Brahma, M. K., and Padmanabhan, P. (2011). Fermentation, isolation, structure, and antidiabetic activity of NFAT-133 produced by Streptomyces strain PM0324667. AMB Express. 1, 42-54. doi: 10.1186/2191-0855-1-42

Li, Y., Maa, D., Sun, D., Wanga, C., Zhang, J., Xie, Y., et al. (2015). Total phenolic, flavonoid content, and antioxidant activity of flour, noodles, and steamed bread made from different colored wheat grains by three milling methods. Crop J. 3, 328-334. doi: 10.1016/j.cj.2015.04.004

Lowry, O. H., Rosebrough, N. J., Farr, A. L., and Randall, R. J. (1951). Protein measurement with the Folin phenol reagent. J. Biol. Chem. 193, 265-275.

Maioli, M., Pes, G. M., Sanna, M., Cherchi, S., Dettori, M., et al. (2008). Sourdoughleavened bread improves postprandial glucose and insulin plasma levels in subjects with impaired glucose tolerance. Acta Diabetol. 45, 91-96. doi: 10.1007/ s00592-008-0029-8

Marklund, S., and Marklund, G. (1974). Involvement of the superoxide anion radical in the autoxidation of pyrogallol and a convenient assay for superoxide dismutase. Eur. J. Biochem. 47, 469-474. doi: 10.1111/j.1432-1033.1974. tb03714.x

Mir, S. A., Naik, H. R., Shah, M. A., Mir, M. M., Wani, M. H., and Bhat, M. A (2014). Indian flat breads: a review. Food Nutr. Sci. 5, 549-561. doi: 10.4236/fns. 2014.56065

Mondal, K. C., Ghosh, K., Mitra, B., Parua, S., and Das Mohapatra, P. K. (2016) "Rice-based fermented foods and beverages: functional and nutraceutical properties," in Fermented Foods, Part II: Technological Intervention, eds R. C. Ray and D. Montet (Boca Raton: CRC Press), 150-176.

Morris, G. M., Huey, R., Lindstrom, W., Sanner, M. F., Belew, R. K., Goodsell, D. S., et al. (2009). Autodock4 and autoDockTools4: automated docking with selective receptor flexibility. J. Comput. Chem. 30, 2785-2791. doi: 10.1002/jcc. 21256

O’Boyle, N. M., Banck, M., James, C. A., Morley, C., Vandermeersch, T. and Hutchison, G. R. (2011). Open babel: an open chemical toolbox. J. Cheminformatics. 3:33. doi: 10.1186/1758-2946-3-33

Osman, M. A. (2011). Effect of traditional fermentation process on the nutrient and antinutrient contents of pearl millet during preparation of Lohoh. J. Saudi Soc. Agric. Sci. 10, 1-6. doi: 10.1016/j.jssas.2010.06.001

Pandey, S., Sree, A., Dash, S. S., Sethi, D. P., and Chowdhury, L. (2013). Diversity of marine bacteria producing beta-glucosidase inhibitors. Microb. Cell Fact. 12, 35-42. doi: 10.1186/1475-2859-12-35

Parimala, K. R., and Sudha, M. L. (2015). Wheat-based traditional flat breads of India. Crit. Rev. Food Sci. Nutr. 55, 67-81. doi: 10.1080/10408398.2011. 647121

Poutanen, K., Flander, L., and Katina, K. (2009). Sourdough and cereal fermentation in a nutritional perspective. Food Microbiol. 26, 693-699. doi 10.1016/j.fm.2009.07.011

Punia, S., and Sandhu, K. S. (2016). Physicochemical and antioxidant properties of different milling fractions of Indian wheat cultivars. Int. J. Pharm. Biol. Sci. 7, 61-66. 
Ramakrishnan, C. (1980). Studies on Indian fermented foods. Baroda J. Nutr. 6, $1-57$.

Rios, J. L., and Recio, M. C. (2005). Medicinal plants and antimicrobial activity. J. Ethnopharmacol. 100, 80-84. doi: 10.1016/j.jep.2005.04.025

Sanner, M. F. (1999). Python: a programming language for software integration and development. J. Mol. Graph. Model. 17, 57-61.

Savitri, and Bhalla, T. C. (2013). Characterization of bhatooru, a traditional fermented food of Himachal Pradesh: microbiological and biochemical aspects. 3 Biotech 3, 247-254. doi: 10.1007/s13205-012-0092-2

Savitri, Thakur, N., Kumar, D., and Bhalla, T. C. (2012). Microbiological and biochemical characterization of seera : a traditional fermented food of Himachal Pradesh. Int. J. Food Ferment. Technol. 2, 49-56. doi: 10.1007/s13205-0120092-2

Shukor, N. A., Camp, J. V., Gonzales, G. B., Staljanssens, D., Karin Struijs, K., Zotti, M. J., et al. (2013). Angiotensin-converting enzyme inhibitory effects by plant phenolic compounds: a study of structure activity relationships. J. Agric. Food Chem. 61, 11832-11839. doi: 10.1021/jf404641v

Tamang, J. P. (2010). Himalayan Fermented Foods: Microbiology. Nutrition and Ethnic Values. Boca Raton: CRC press, 117-136.

Tamang, J. P., Shin, D. H., Jung, S. J., and Chae, S. W. (2016). Functional properties of microorganisms in fermented foods. Front. Microbiol. 7:578. doi: 10.3389/ fmicb.2016.00578

Tamang, J. P., Thapa, N., Tamang, B., Rai, A., and Chettri, R. (2015). "Microorganisms in fermented foods and beverages," in Health Benefits of Fermented Foods and Beverages, ed. J. P. Tamang (Boca Raton: CRC press), 1-110. doi: 10.1201/b18279
Tripathi, V. R., Kumar, S., and Garg, S. K. (2011). A study on trypsin, Aspergillus flavus and Bacillus sp. protease inhibitory activity in Cassia tora (L.) syn Senna tora (L.) Roxb. seed extract. BMC Complem. Altern. M. 11, 56-64. doi: 10.1186/ 1472-6882-11-56

Wright, J. R., Colby, H. D., and Miles, P. R. (1981). Cytosolic factors which affect microsomal lipid peroxidation in lung and liver. Arch. Biochem. Biophys. 206, 296-304. doi: 10.1016/0003-9861(81)90 095-3

Yen, G. C., and Chen, H. Y. (1995). Antioxidant activity of various tea extracts in relation to their antimutagenicity. J. Agric. Food Chem. 43, 27-32. doi: 10.1021/ jf00049a007

Yonzan, H., and Tamang, J. P. (2010). Microbiology and nutritional value of selroti, an ethnic fermented cereal food of the Himalayas. Food Biotechnol. 24, 227-247. doi: 10.1080/08905436.2010.507133

Conflict of Interest Statement: The authors declare that the research was conducted in the absence of any commercial or financial relationships that could be construed as a potential conflict of interest.

Copyright (0 2019 Hor, Ray, Pal, Ghosh, Soren, Maiti, Bera, Singh, Dwivedi, Takó, DasMohapatra and Mondal. This is an open-access article distributed under the terms of the Creative Commons Attribution License (CC BY). The use, distribution or reproduction in other forums is permitted, provided the original author(s) and the copyright owner(s) are credited and that the original publication in this journal is cited, in accordance with accepted academic practice. No use, distribution or reproduction is permitted which does not comply with these terms. 